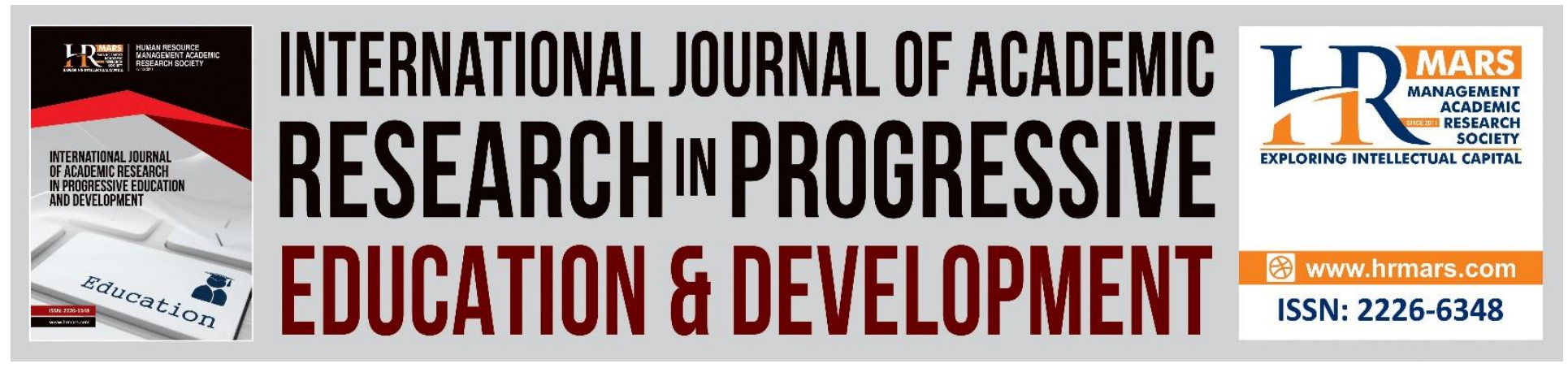

\title{
Administrative Management Quality Standard and Teachers' Practices Compliance on School Sports Safety
}

Mai Shihah Abdullah, Julismah Jani, Mohd Izwan Shahril, Rozaireen Muszali, Muhammad Amirul Adnan \& Mohd. Esa Baruji

To Link this Article: http://dx.doi.org/10.6007/IJARPED/v10-i2/9801

DOI:10.6007/IJARPED/v10-i2/9801

Received: 05 April 2021, Revised: 30 April 2021, Accepted: 20 May 2021

Published Online: 15 June2021

In-Text Citation: (Abdullah et al., 2021)

To Cite this Article: Abdullah, M. S., Jani, J., Shahril, M. I., Muszali, R., Adnan, M. A., \& Baruji, M. E. (2021). Administrative Management Quality Standard and Teachers' Practices Compliance on School Sports Safety. International Journal of Academic Research in Progressive Education and Development, 10(2), 648-664.

Copyright: (C) 2021 The Author(s)

Published by Human Resource Management Academic Research Society (www.hrmars.com)

This article is published under the Creative Commons Attribution (CC BY 4.0) license. Anyone may reproduce, distribute, translate and create derivative works of this article (for both commercial and non-commercial purposes), subject to full attribution to the original publication and authors. The full terms of this license may be seen at: http://creativecommons.org/licences/by/4.0/legalcode

Vol. $10(2)$ 2021, Pg. 648 - 664

http://hrmars.com/index.php/pages/detail/IJARPED

JOURNAL HOMEPAGE

Full Terms \& Conditions of access and use can be found at http://hrmars.com/index.php/pages/detail/publication-ethics 


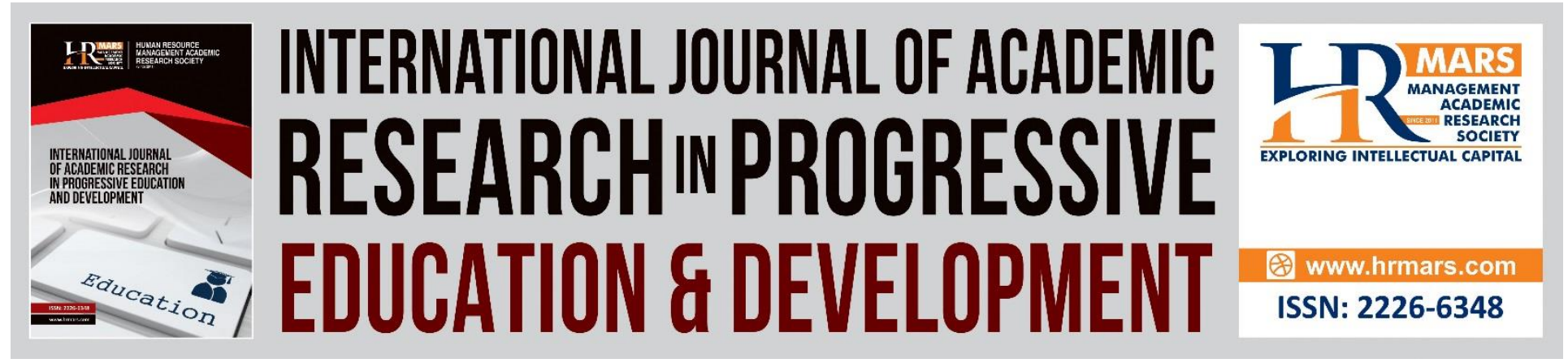

\title{
Administrative Management Quality Standard and Teachers' Practices Compliance on School Sports Safety
}

\author{
Mai Shihah Abdullah ${ }^{1}$, Julismah Jani², Mohd Izwan Shahril ${ }^{3}$, \\ Rozaireen Muszali ${ }^{4}$, Muhammad Amirul Adnan ${ }^{5} \&$ Mohd. Esa \\ Baruji 6
}

${ }^{1}$ Faculty of Science and Mathematics, Sultan Idris Education University, Perak Malaysia, ${ }^{2,3,4 \& 5}$ Faculty of Sports Science and Coaching, Sultan Idris Education University, Perak Malaysia,

${ }^{6}$ National Institute of Occupational Safety and Health (NIOSH), Malaysia

Email: mai.shihah@fsmt.upsi.edu.my

\begin{abstract}
The purpose of this study is to investigate the accord of sports safety aspects to the quality standard of the school administrative management and teachers' compliance practices. A survey was administered using questionnaires on 268 schools' Physical Education stakeholders as respondents using random stratified sampling at 109 primary and secondary urban and rural schools. This perception study revealed that the quality standard of administrative management on sports safety at all schools was excellent. Similarly, for the compliance of teachers' practices. There was no significant difference in the quality standards of the administrative management and the compliance of teachers' practices on sports safety in primary and secondary schools between urban and rural areas. A very strong and significant relationship were demonstrated between the quality standard of the administrative management and the compliance of teachers' practices on sports safety. The study implicates that good management and the teachers' compliance practises on the sports activities are reassured when the school takes note and action according to the Safe School Policy, School Safety Program, and conformed to the standard operating procedures.
\end{abstract}

Keywords: Sports Safety, Administrative Management Quality, Teachers' Practices Compliance

\section{Introduction}

According to Maslow's Theory of Hierarchy of Needs, assurance on the quality of safety is a priority to oneself. The theory sets out five needs that one must meet including safety. Demands for safety needs instinctively motivate one to manage safety well to ensure well-being (Mawarni 
et al., 2006). In that context, good safety management based on standard guidelines is very necessary especially in school organizations so that students' safety is guaranteed.

In Malaysia, the Ministry of Education (MOE) has prepared a handbook on the management of Physical Education and Health Education-PEHE (Inspectorate Board, 2019) related to sports safety. In paragraph viii (page ix), it is explained that the objective of preparing the book is to enhance the standard of safety before, during, and after implementing PEHE activities by providing some guidance in the aspect of safety in the management of PEHE subjects. The handbook is in line with the Professional Circular Letter of the Ministry of Education Malaysia No.5/2016 related to safety guidelines during the teaching of Physical Education and Health Education as well as co-curricular activities and sports inside and outside the school grounds.

Despite the proper documentation prepared by the Ministry of Education on the safety of the sport in school, news of accidents that occur during sports activities is reported through the press. For instance, an incident related to Form 4 student who was injured in the left eye due to being stabbed by an arrow accidentally released by his friends while undergoing archery training on the school field (Harian, 2020). According to the witness, it was found that there was no teacher monitoring during the incident and the involved students had taken archery equipment at the store on themselves to do archery training to represent the district in the competition at the State Schools Sports level.

The accident incident has received an unpleasant reaction, especially parents whose children are still in school because it is feared that such incidents could happen to their children. Therefore, schools need to take precautionary measures to prevent the recurrence of such accidents. Ideally, schools should constantly monitor, inspect, and evaluate the infrastructure, equipment, and manage the sports activities that may pose potential risks to the safety of students, especially in Physical Education, co-curriculum, and sports activities.

Schools are entities under the legislation of the Ministry of Education Malaysia; hence it is appropriate that all parties related to education should assist in identifying the safety standard regarding the condition of facilities, equipment, and management of sports activities in schools. Aspects of student safety need to be given serious attention by the school, especially when conducting Physical Education activities, co-curriculum, and sports programs. Every teacher involved in such activities or programs must take safety measures by following the guidelines and instructions in the Professional Circular Letter of the Ministry of Education Malaysia related to the students safety in schools. Besides, teachers also need to ensure that students follow the instructions and guidelines in the usage and management of sports equipment.

In this regard, school administrators and teachers need to ensure a safe school environment and infrastructure by implementing the Safe School Policy (School Division, MOE, 2002). The objective of the implementation of the Safe School Policy is to increase the understanding and appreciation that safety should be the main agenda in all aspects of education in schools. School administrators and teachers also need to manage the Hygiene, Health, and Safety (coined as 3K) program as recommended by the School Division, Ministry of Education Malaysia (2004). The 3K program is geared towards creating a school environment that encourages teaching and learning activities towards cultivating a safe and prosperous school. The role implies that the school, namely the administrators and teachers are not only responsible in the event of an accident, but also responsible for preventing accidents. 
However, to what extent can the school be able to manage the safety of students in conducting Physical Education, sports, and co-curricular activities at school? Accordingly, school management should uphold to the standard operating procedures with the good practices by the teachers in conducting the monitoring process.

Therefore, the purpose of this study was to investigate the school's administrative management quality and the compliance of teachers' practices on sports safety aspects in schools. The results of this study provide input and indicators to identify the safety standard regarding infrastructure and management of sports activities in schools. The report of this study can be submitted to the Ministry of Education Malaysia, the community, and parents so that they are confident in students' safety in sports at school. Consequently, schools need to regularly conduct an audit of sports facilities' safety compliance in schools to prevent accidents.

\section{Research Objectives}

a. To identify the quality standard of school administrative management on sports safety in primary and secondary schools of urban and rural areas.

b. To identify the compliance standard of teachers' practices on sports safety in primary and secondary schools of urban and rural areas.

c. To compare the quality of school administrative management on sports safety in primary and secondary schools between urban and rural areas.

d. To compare the teachers' compliance on sports safety in primary and secondary schools between urban and rural areas.

e. To assess the relationship between the quality of school administrative management and the compliance of teachers' practices on sports safety in primary and secondary schools of urban and rural areas.

\section{Research Methodology}

The design of this study was descriptive involving the survey method. The approach of collecting quantitative data was based on questionnaire instruments. The process of collecting data began with the setting of the context that is to categorize the safety elements of the facilities, equipment, and implementation of sports in schools. The category of safety elements was developed by referring to the handbook of the management of Physical Education and Health Education - PEHE (Inspectorate Board, 2019) as well as Professional Circular Letter related to students' safety guide during Physical Education and Health Education as well as co-curricular and sports activities inside and outside the school area.

The following process was to develop a questionnaire instrument on the safety of facilities, equipment, and management of sports activities in schools. The instrument on safety management in sports by the administrator contains checklist and questions elements that are evaluated on a score of 0 to 2 . While the instrument to measure the standard of practice of Physical Education teachers is in the form of a Likert scale from 0 to 5.

The data collected were analyzed to identify the standard of achievement of safety management in sports by school administrators. The data was transformed from a score of 0 to 10 to the achievement value as follows: 
Vol. 10, No. 2, 2021, E-ISSN: 2226-6348 @ 2021 HRMARS

$\begin{array}{ll}\text { Achievement Value } & \text { Standard of Management Quality } \\ 8.21-10.00 & \text { Very Good } \\ 6.41-8.20 & \text { Good } \\ 4.61-6.40 & \text { Moderate } \\ 2.81-4.60 & \text { Weak } \\ 0.00-2.80 & \text { Very Weak }\end{array}$

Meanwhile, the data analyzed to identify the standard of achievement of teachers' practices on safety in sports in schools for the achievement index was as follows:

$\begin{array}{ll}\text { Achievement Value } & \text { Standard of Practice Compliance } \\ 4.21-5.00 & \text { Very High } \\ 3.41-4.20 & \text { High } \\ 2.61-3.40 & \text { Moderate } \\ 1.81-2.60 & \text { Low } \\ 0.00-1.80 & \text { Very Low }\end{array}$

The study samples consisted of physical education teachers, co-curriculum teachers, sports secretaries, physical education committees, panel heads, senior assistants, and principals/ headmasters in primary and secondary schools, urban and rural areas were randomly selected by stratified sampling. The researchers chose the study location in bangsar/ pudu zone in the federal territory of kuala lumpur and the batang padang and muallim districts of perak state. The selection was based on obtaining a balanced number of sample sizes as well as the diversity of infrastructure environment in an urban and rural location.

The process of calculating the sample size began by determining the number of populations at the study site.both the margin of error (confidence interval) and confidence standard were set at 10 and $95 \%$ respectively. The sample size was calculated and determined according to smith (2018). The number of primary and secondary schools studied was 109 (59 primary schools and 50 secondary schools) while the sample of teachers teaching physical education, coordinating cocurriculum and sports activities was 268 (137 primary schools and 131 secondary schools).

Once the research samples identified, they were contacted for consent to participate in this study. Permission from the malaysia ministry of education, state and district education departments as well as the chief administrator of the schools involved were graned prior to conducting this study. Enumerators were appointed in each school to assist in the management of data collection.

Descriptive data were analyzed and reported in mean, standard deviation, and standard of sports safety. Inference data analysis for comparison carried out by using a t-test while Pearson correlation for relationship. Inferential statistical test analysis to determine the significant differences between the study variables was set at the significance standard, $\alpha=0.05$.

\section{Results and Discussion}

In this section, the researchers report on the findings of the study to identify the quality of administrative management and the compliance of teachers' practices on sports safety in primary and secondary schools of urban and rural areas. Next, the researchers made a 
comparison of the quality of administrative management and the compliance of teachers' practices on sports safety in primary and secondary schools between urban and rural areas. This is followed by assessing the relationship between the quality of administrative management and the compliance of teachers' practices on sports safety in primary and secondary schools of urban and rural areas.

The Quality Standard of Administrative Management on Sports Safety in Primary and Secondary Schools

Descriptive data from the study to identify the quality of administrative management on sports safety in primary and secondary schools of urban and rural areas is displayed in Table 1. The results showed the quality of safety management in sports by administrators in 59 urban and rural primary schools were at a very good standard (Mean 8.63, SD 1.38). For urban schools ( $n=$ 13), the quality of implementation of Safe School Program management was at a moderate standard (Mean $=6.22 ; S D=4.47$ ) compared to rural schools $(n=46)$ which achieved a good standard (Mean = 7.13; SD = 3.21). The quality of management of the implementation of the $3 \mathrm{~K}$ program, namely Health, Hygiene, and Safety for urban and rural schools $(n=59)$ was at a very good standard (Mean $=9.03 ; \mathrm{SD}=1.45$ ). The study revealed that the standard of school compliance $(n=59)$ with the safety policy and action procedures in the sports store/sports management room was very good based on the achievement of Mean = 9.35 and SD = 1.68. Similarly, the standard of school compliance with safety policies and action procedures in the field/ court/ open hall/ indoor hall was also very good (Mean $=9.32 ;$ SD $=2.07$ ). 
INTERNATIONAL JOURNAL OF ACADEMIC RESEARCH IN PROGRESSIVE EDUCATION AND DEVELOPMENT

Vol. 10, No. 2, 2021, E-ISSN: 2226-6348 @ 2021 HRMARS

Table 1. The quality standard of administrative management on sports safety in urban and rural primary schools

\begin{tabular}{|c|c|c|c|c|c|c|c|c|c|}
\hline \multirow{2}{*}{$\begin{array}{l}\text { Aspects of safety } \\
\text { management in sports }\end{array}$} & \multicolumn{3}{|c|}{ Urban $(n=13)$} & \multicolumn{3}{|c|}{ Rural (n= 46) } & \multicolumn{3}{|c|}{ Overall $(n=59)$} \\
\hline & Mean & SD & Standard & Mean & SD & Standard & Mean & SD & Standard \\
\hline $\begin{array}{l}\text { - Implementation of } \\
\text { the management of } \\
\text { Safe School Program }\end{array}$ & 6.22 & 4.47 & Moderate & 7.19 & 3.21 & Good & 6.98 & 3.51 & Good \\
\hline $\begin{array}{l}\text { - Implementation of } 3 \mathrm{~K} \\
\text { program related to } \\
\text { safety management }\end{array}$ & 9.14 & 1.22 & Very Good & 9.00 & 1.51 & $\begin{array}{l}\text { Very } \\
\text { Good }\end{array}$ & 9.03 & 1.45 & $\begin{array}{l}\text { Very } \\
\text { Good }\end{array}$ \\
\hline $\begin{array}{l}\text { - Implementation in } \\
\text { management of } \\
\text { safety policies on } \\
\text { Physical Education, } \\
\text { co-curricular and } \\
\text { sports activities in } \\
\text { schools }\end{array}$ & 8.39 & 2.66 & $\begin{array}{l}\text { Very } \\
\text { Good }\end{array}$ & 8.51 & 1.85 & $\begin{array}{l}\text { Very } \\
\text { Good }\end{array}$ & 8.49 & 2.03 & $\begin{array}{l}\text { Very } \\
\text { Good }\end{array}$ \\
\hline $\begin{array}{l}\text { - Compliance with } \\
\text { safety policies and } \\
\text { action procedures in } \\
\text { sports stores/ sports } \\
\text { management rooms }\end{array}$ & 8.92 & 2.78 & $\begin{array}{l}\text { Very } \\
\text { Good }\end{array}$ & 9.47 & 1.24 & $\begin{array}{l}\text { Very } \\
\text { Good }\end{array}$ & 9.35 & 1.68 & $\begin{array}{l}\text { Very } \\
\text { Good }\end{array}$ \\
\hline $\begin{array}{l}\text { Compliance with } \\
\text { safety policies and } \\
\text { action procedures in } \\
\text { field/ court/ open } \\
\text { hall/ indoor hall }\end{array}$ & 9.10 & 2.77 & $\begin{array}{l}\text { Very } \\
\text { Good }\end{array}$ & 9.38 & 1.86 & $\begin{array}{l}\text { Very } \\
\text { Good }\end{array}$ & 9.32 & 2.07 & $\begin{array}{l}\text { Very } \\
\text { Good }\end{array}$ \\
\hline $\begin{array}{l}\text { - Overall standard of } \\
\text { sports safety } \\
\text { management }\end{array}$ & 8.35 & 1.76 & $\begin{array}{l}\text { Very } \\
\text { Good }\end{array}$ & 8.71 & 1.26 & $\begin{array}{l}\text { Very } \\
\text { Good }\end{array}$ & 8.63 & 1.38 & $\begin{array}{l}\text { Very } \\
\text { Good }\end{array}$ \\
\hline
\end{tabular}


INTERNATIONAL JOURNAL OF ACADEMIC RESEARCH IN PROGRESSIVE EDUCATION AND

DEVELOPMENT

Vol. 10, No. 2, 2021, E-ISSN: 2226-6348 @ 2021 HRMARS

Table 2. The quality standard of administrative management on sports safety in urban and rural secondary schools

\begin{tabular}{|c|c|c|c|c|c|c|c|c|c|}
\hline \multirow{2}{*}{$\begin{array}{l}\text { Aspects of safety } \\
\text { management in sports }\end{array}$} & \multicolumn{3}{|c|}{ Urban $(n=36)$} & \multicolumn{3}{|c|}{ Rural (n=14) } & \multicolumn{3}{|c|}{ Overall $(n=50)$} \\
\hline & Mean & SD & Standard & Mean & SD & Standard & Mean & SD & Standard \\
\hline $\begin{array}{l}\text { - Implementation of the } \\
\text { management of Safe } \\
\text { School Program }\end{array}$ & 6.04 & 3.68 & Moderate & 7.45 & 3.15 & Good & 6.43 & 3.56 & Moderate \\
\hline $\begin{array}{l}\text { - Implementation of } 3 \mathrm{~K} \\
\text { program related to } \\
\text { safety management }\end{array}$ & 8.36 & 2.51 & Very Good & 7.98 & 2.94 & Good & 8.26 & 2.61 & Very Good \\
\hline $\begin{array}{l}\text { - Implementation in } \\
\text { management of safety } \\
\text { policies on Physical } \\
\text { Education, co-curricular } \\
\text { and sports activities in } \\
\text { schools }\end{array}$ & 7.71 & 2.34 & Good & 8.63 & 1.89 & $\begin{array}{l}\text { Very } \\
\text { Good }\end{array}$ & 7.97 & 2.24 & Good \\
\hline $\begin{array}{l}\text { - Compliance with safety } \\
\text { policies and action } \\
\text { procedures in sports } \\
\text { stores/ sports } \\
\text { management rooms }\end{array}$ & 9.32 & 1.06 & $\begin{array}{l}\text { Very } \\
\text { Good }\end{array}$ & 8.64 & 1.98 & $\begin{array}{l}\text { Very } \\
\text { Good }\end{array}$ & 9.13 & 1.39 & $\begin{array}{l}\text { Very } \\
\text { Good }\end{array}$ \\
\hline $\begin{array}{l}\text { - Compliance with safety } \\
\text { policies and action } \\
\text { procedures in field/ } \\
\text { court/ open hall/ } \\
\text { indoor hall }\end{array}$ & 9.53 & 1.35 & $\begin{array}{l}\text { Very } \\
\text { Good }\end{array}$ & 9.04 & 1.81 & $\begin{array}{l}\text { Very } \\
\text { Good }\end{array}$ & 9.39 & 1.49 & $\begin{array}{l}\text { Very } \\
\text { Good }\end{array}$ \\
\hline $\begin{array}{l}\text { - Overall standard of } \\
\text { sports safety } \\
\text { management }\end{array}$ & 8.19 & 1.42 & $\begin{array}{l}\text { Very } \\
\text { Good }\end{array}$ & 8.35 & 1.80 & $\begin{array}{l}\text { Very } \\
\text { Good }\end{array}$ & 8.24 & 1.52 & $\begin{array}{l}\text { Very } \\
\text { Good }\end{array}$ \\
\hline
\end{tabular}

This study prevailed both urban and rural secondary schools showed the highest scores on compliance with safety policies and action procedures in field/ court/ open hall/ indoor hall respectively at a very good standard (Mean $=9.53, S D=1.35$; Mean=9.04, SD =1.81). The lowest score for both urban secondary schools (medium: Mean $=6.04, S D=3.68$ ) and rural (good: Mean $=7.45, \mathrm{SD}=3.15$ ) is on the management of the Safe Schools Program. If all aspects were considered, the quality of sports safety management by administrators for both urban and rural secondary schools was very good respectively (Mean =8.19, $S D=1.42$; Mean=8.35, $S D=1.80$ ). In general, the quality of secondary school administrators in ensuring sports safety management was very good (Mean $=8.24, \mathrm{SD}=1.52$ ).

The quality of sports safety management by primary and secondary school administrators as a whole was very good. Thus, indicating that administrators of the primary and secondary schools in the urban and rural have managed the sport safety climate in accordance to the Professional 
Vol. 10, No. 2, 2021, E-ISSN: 2226-6348 @ 2021 HRMARS

Circular Letter, Safe School Policy, and implemented the 3K program by following the standard operating procedures.

The administrators successfully educate the school community to prioritize safety aspects in the activities carried out. The school also managed to prepare an action plan for the school community to understand and take the necessary action to avoid accidents. It was also found that the schools studied had a robust system to address any issues related to school safety, health, and cheerfulness through the $3 \mathrm{~K}$ program. The administrators also monitor the physical environment of the school, especially the basic facilities to be safe, clean, healthy, and cheerful.

Standards of Teacher Practice Compliance with Sports Safety in Primary and Secondary Schools Table 3 displays an analysis of descriptive data on the compliance of the teacher practice with sports safety aspects in primary and secondary schools of urban and rural areas.

Table 3. Quality standard of teachers' practice compliance with sports safety aspects in urban and rural primary schools

\begin{tabular}{|c|c|c|c|c|c|c|c|c|c|}
\hline \multirow{2}{*}{$\begin{array}{l}\text { Aspects of } \\
\text { teacher in sports } \\
\text { safety practices }\end{array}$} & \multicolumn{3}{|c|}{ Urban $(n=35)$} & \multicolumn{3}{|c|}{ Rural $(n=102)$} & \multicolumn{3}{|c|}{ Overall $(n=137)$} \\
\hline & Mean & SD & Standard & Mean & SD & Standard & Mean & SD & Standard \\
\hline - Refer to & & & Very & & & & & & \\
\hline $\begin{array}{l}\text { documents } \\
\text { related to } \\
\text { sports safety }\end{array}$ & 4.29 & .58 & High & 3.93 & .70 & High & 4.02 & .68 & High \\
\hline $\begin{array}{l}\text { - Complete } \\
\text { teacher attire }\end{array}$ & 4.69 & .63 & $\begin{array}{l}\text { Very } \\
\text { High }\end{array}$ & 4.59 & .76 & $\begin{array}{l}\text { Very } \\
\text { High }\end{array}$ & 4.61 & .73 & $\begin{array}{l}\text { Very } \\
\text { High }\end{array}$ \\
\hline - Use of safe & & & Very & & & Very & & & Very \\
\hline $\begin{array}{l}\text { areas while } \\
\text { teaching }\end{array}$ & 4.52 & .52 & High & 4.45 & .51 & High & 4.47 & .51 & High \\
\hline - Student safety & & & Very & & & & & & Very \\
\hline $\begin{array}{l}\text { related to } \\
\text { health and } \\
\text { attire }\end{array}$ & 4.27 & .67 & High & 4.19 & .65 & High & 4.21 & .66 & High \\
\hline - Good sports & & & Very & & & Very & & & Very \\
\hline $\begin{array}{l}\text { equipment } \\
\text { condition while } \\
\text { teaching }\end{array}$ & 4.41 & .59 & High & 4.38 & .51 & High & 4.39 & .53 & High \\
\hline - Safe use of & & & Very & & & Very & & & Very \\
\hline $\begin{array}{l}\text { sports } \\
\text { equipment by } \\
\text { students }\end{array}$ & 4.32 & .75 & High & 4.43 & .69 & High & 4.40 & .71 & High \\
\hline - Inform students & & & Very & & & Very & & & Very \\
\hline $\begin{array}{l}\text { about sports } \\
\text { safety }\end{array}$ & 4.54 & .52 & High & 4.44 & .49 & High & 4.46 & .50 & High \\
\hline
\end{tabular}


Vol. 10, No. 2, 2021, E-ISSN: 2226-6348 @ 2021 HRMARS

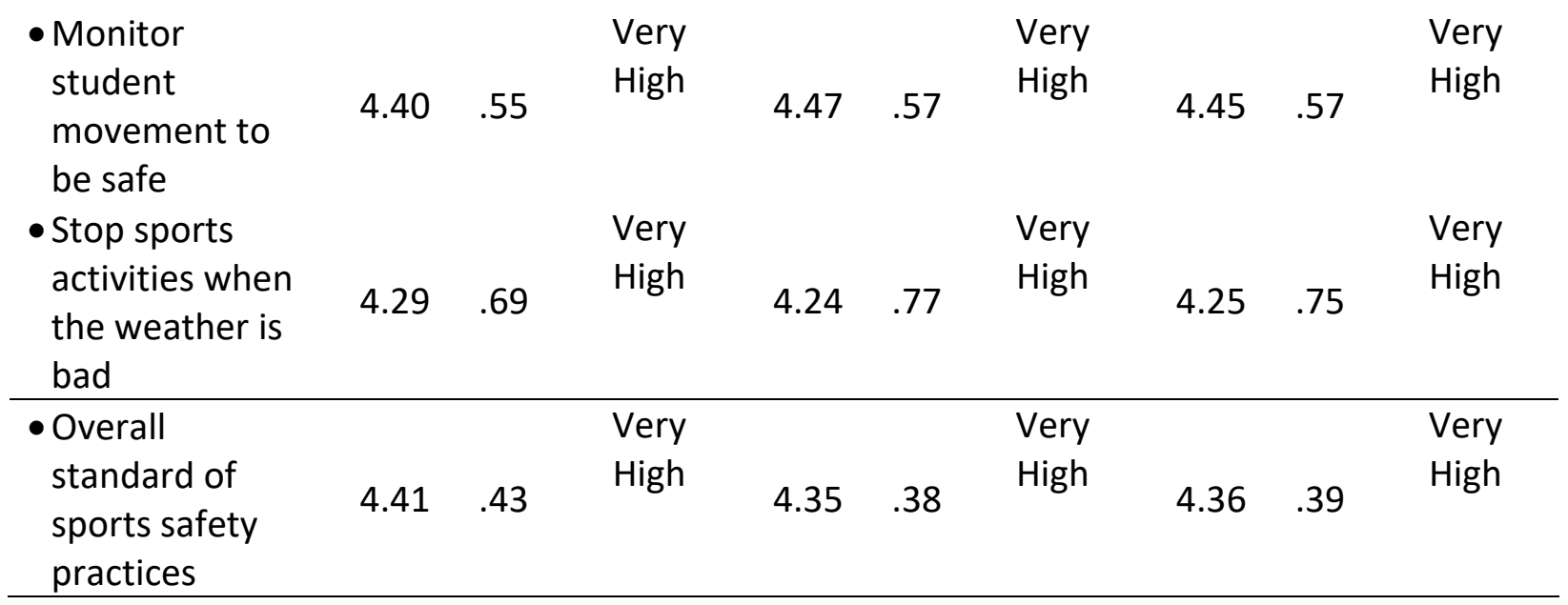

The results of the study showed that in overall, teachers' practice of sports safety aspects in urban and rural primary schools $(n=137)$ was at a very high standard (Mean $=4.36$; SD $=.39$ ). The teachers studied in urban and rural primary schools have practiced all sports safety aspects at a very high standard, respectively at Mean $=4.41 ; S D=0.43$ and Mean $=4.35 ;$ SD $=0.38$. Compliance with the practice of "complete sports attire for a sports teacher" was the highest for both urban and rural primary schools respectively at Mean $=4.69, \mathrm{SD}=.63$; Mean $=4.59, \mathrm{SD}=$ .76. The lowest compliance score was for an item "refer to documents related to sports safety" for rural primary schools (Mean $=3.93, S D=0.70$ ). Among urban school teachers, the lowest compliance was the safety aspect of "students related to health and attire" (Mean $=4.27, \mathrm{SD}=$ .67). Overall, the aspect of "referring to documents related to sports safety" with the lowest score (Mean $=4.02, \mathrm{SD}=.68$ ) should be given attention. Similarly to the teachers' practice compliance "to stop sports activities when the weather is bad" (Mean $=4.25, \mathrm{SD}=0.75$ ). The compliance to other sports safety aspects was very satisfactory and very high.

A descriptive data analysis of the achievement of teacher's practice compliance with sports safety aspects of urban and rural secondary schools conducted among 131 Physical Education teachers, Co-curriculum and sports coordinators surveyed as in Table 4. 
INTERNATIONAL JOURNAL OF ACADEMIC RESEARCH IN PROGRESSIVE EDUCATION AND DEVELOPMENT

Vol. 10, No. 2, 2021, E-ISSN: 2226-6348 @ 2021 HRMARS

Table 4. Quality standard of teachers' practice compliance with sports safety aspects in urban and rural secondary schools

\begin{tabular}{|c|c|c|c|c|c|c|c|c|c|}
\hline \multirow{2}{*}{$\begin{array}{l}\text { Aspects of } \\
\text { teacher in sports } \\
\text { safety practices }\end{array}$} & \multicolumn{3}{|c|}{ Urban $(n=92)$} & \multicolumn{3}{|c|}{ Rural ( $n=39$ ) } & \multicolumn{3}{|c|}{ Overall $(n=131)$} \\
\hline & Mean & SD & Standard & Mean & SD & Standard & Mean & SD & Standard \\
\hline $\begin{array}{l}\text { Refer to } \\
\text { documents } \\
\text { related to } \\
\text { sports safety }\end{array}$ & 4.06 & .70 & High & 3.92 & .76 & High & 4.02 & .72 & High \\
\hline $\begin{array}{l}\text { - Complete } \\
\text { teacher attire }\end{array}$ & 4.60 & .87 & $\begin{array}{l}\text { Very } \\
\text { High }\end{array}$ & 4.62 & .78 & $\begin{array}{l}\text { Very } \\
\text { High }\end{array}$ & 4.60 & .84 & $\begin{array}{l}\text { Very } \\
\text { High }\end{array}$ \\
\hline $\begin{array}{l}\text { - Use of safe } \\
\text { areas while } \\
\text { teaching }\end{array}$ & 4.17 & .66 & High & 4.35 & .55 & $\begin{array}{l}\text { Very } \\
\text { High }\end{array}$ & 4.22 & .63 & $\begin{array}{l}\text { Very } \\
\text { High }\end{array}$ \\
\hline $\begin{array}{l}\text { Student safety } \\
\text { related to } \\
\text { health and } \\
\text { attire }\end{array}$ & 4.23 & .68 & $\begin{array}{l}\text { Very } \\
\text { High }\end{array}$ & 4.29 & .49 & $\begin{array}{l}\text { Very } \\
\text { High }\end{array}$ & 4.25 & .63 & $\begin{array}{l}\text { Very } \\
\text { High }\end{array}$ \\
\hline $\begin{array}{l}\text { - Good sports } \\
\text { equipment } \\
\text { condition while } \\
\text { teaching }\end{array}$ & 4.13 & .74 & High & 4.28 & .78 & $\begin{array}{l}\text { Very } \\
\text { High }\end{array}$ & 4.18 & .75 & High \\
\hline $\begin{array}{l}\text { - Safe use of } \\
\text { sports } \\
\text { equipment by } \\
\text { students }\end{array}$ & 4.39 & .66 & $\begin{array}{l}\text { Very } \\
\text { High }\end{array}$ & 4.60 & .63 & $\begin{array}{l}\text { Very } \\
\text { High }\end{array}$ & 4.45 & .66 & $\begin{array}{l}\text { Very } \\
\text { High }\end{array}$ \\
\hline $\begin{array}{l}\text { - Inform } \\
\text { students about } \\
\text { sports safety }\end{array}$ & 4.26 & .65 & $\begin{array}{l}\text { Very } \\
\text { High }\end{array}$ & 4.35 & .50 & $\begin{array}{l}\text { Very } \\
\text { High }\end{array}$ & 4.29 & .61 & $\begin{array}{l}\text { Very } \\
\text { High }\end{array}$ \\
\hline $\begin{array}{l}\text { - Monitor } \\
\text { student } \\
\text { movement to } \\
\text { be safe }\end{array}$ & 4.39 & .61 & $\begin{array}{l}\text { Very } \\
\text { High }\end{array}$ & 4.50 & .54 & $\begin{array}{l}\text { Very } \\
\text { High }\end{array}$ & 4.42 & .59 & $\begin{array}{l}\text { Very } \\
\text { High }\end{array}$ \\
\hline $\begin{array}{l}\text { - Stop sports } \\
\text { activities when } \\
\text { the weather is } \\
\text { bad }\end{array}$ & 4.16 & .78 & High & 4.56 & .52 & $\begin{array}{l}\text { Very } \\
\text { High }\end{array}$ & 4.28 & .74 & $\begin{array}{l}\text { Very } \\
\text { High }\end{array}$ \\
\hline $\begin{array}{l}\text { - Overall } \\
\text { standard of } \\
\text { sports safety } \\
\text { practices }\end{array}$ & 4.27 & .52 & $\begin{array}{l}\text { Very } \\
\text { High }\end{array}$ & 4.38 & .40 & $\begin{array}{l}\text { Very } \\
\text { High }\end{array}$ & 4.30 & .49 & $\begin{array}{l}\text { Very } \\
\text { High }\end{array}$ \\
\hline
\end{tabular}


Overall results demonstrate the compliance of the teachers' practice with sports safety aspects in urban and rural secondary schools $(n=131$ ) was at a very high standard (Mean $=4.30 ; S D=$ .49). All teachers in urban and rural secondary schools have complied to all sports safety aspects at a very high standard, respectively at Mean $=4.27$; SD $=0.52$ and Mean 4.38; $S D=0.40$. Compliance to the practice of "sports teachers' with complete sports attire" was the highest for both urban and rural secondary schools respectively at Mean $=4.60, \mathrm{SD}=.87$; Mean $=4.62, \mathrm{SD}=$ .78. Among secondary school teachers, the aspect "refer to documents related to sports safety" obtained the lowest scores of both urban (Mean $=4.06, \mathrm{SD}=.70$ ) and rural (Mean $=3.92, \mathrm{SD}=$ 0.72 ), with overall achievement (Mean $=4.02, S D=0.72$ ). Similarly with the aspect of "ensuring the good sports equipment condition while teaching" (Mean $=4.18, \mathrm{SD}=.75$ ).

Among the less compliance practices by urban school teachers was the "reassurance of good sports equipment condition while teaching" (Mean $=4.13, \mathrm{SD}=.74$ ) and "the use of safe areas while teaching" (Mean $=4.17, \mathrm{SD}=.66$ ). The study also found compliance with "the practice of stopping sports activities when the weather is bad" was given less attention among urban secondary school teachers (Mean $=4.16, \mathrm{SD}=.78$ ). The standard of practice compliance with other sports safety aspects was very satisfactory and very high.

The compliance of practice of the teachers with sports safety aspects in primary and secondary schools of urban and rural areas was at a very high standard. The results of the study illustrated that all the teachers studied have complied with sports safety practices at a very high standard such as refer to documents related to sports safety in their lesson planning. Teachers wear complete sports attire during sports activities. While teaching, teachers make sure the area used is large enough to accommodate the number of students and is safe such as away from ditches, flat surface, no pebbles, dry, and hygiene areas. Similarly, teachers ensure that less healthy students do not participate in sports activities, and for those who attend Physical Education classes or sports activities, they must wear complete sports attire. Before and during the lesson, teachers check and make sure sports equipment is in good condition and tell students about the correct way when using sports equipment. Students are reminded not to try dangerous equipment such as javelins, shot puts, discus, and others without receiving instructions from the teacher, and the movement of students is monitored to be safe. The teachers immediately stop the sports activity and move to a safe place when the sound of thunder was heard, lightning appeared in the sky, and prolonged drizzle.

The compliance of teachers' practices with sports safety was based on the information contained in the Handbook of Management of Physical Education and Health Education (PEHE) subject (Inspectorate Board, 2019). In item 1.7 on the PEHE Teaching and Learning Implementation Rules referred to in paragraph e. that is, teachers are responsible for ensuring the safety of students during, whether inside or outside the classroom, responsible for taking out, using and storing $\mathrm{PEHE} /$ sports equipment even with the help of students, and ensuring that the area used for the teaching and learning of PEHE is in good and managed condition. The compliance of the teacher practices studied was also based on Circular No. 1/1995, Circular No. 9/2000, and MOE Circular No. 5/2016 related to safety guidelines during the teaching of Physical Education and Health Education as well as co-curricular activities and sports inside and outside the school grounds. 
INTERNATIONAL JOURNAL OF ACADEMIC RESEARCH IN PROGRESSIVE EDUCATION AND

DEVELOPMENT

Vol. 10, No. 2, 2021, E-ISSN: $2226-6348$ @ 2021 HRMARS

\section{Comparison of Administrative Management Quality and Teachers' Practice Compliance with Sports Safety}

The inferential data analysis on the comparison of administrative management and teachers' practice compliance with sports safety in primary and secondary schools between urban and rural areas is as shown in Table 5.

Table 5. Comparison of administrative management quality and teachers' practice compliance with sports safety

\begin{tabular}{|c|c|c|c|c|c|}
\hline & $\mathbf{n}$ & $d f$ & $T$ & sig & $\begin{array}{c}\text { Mean } \\
\text { Difference }\end{array}$ \\
\hline $\begin{array}{l}\text { - Administrative management of sports safety in } \\
\text { urban and rural primary schools. }\end{array}$ & 59 & 57 & -.822 & .414 & -3.587 \\
\hline $\begin{array}{l}\text { - Administrative management of sports safety in } \\
\text { urban and rural secondary schools. }\end{array}$ & 50 & 48 & -.316 & .753 & -1.531 \\
\hline $\begin{array}{l}\text { - Administrative management of sports safety } \\
\text { between primary and secondary schools. }\end{array}$ & 109 & 107 & 1.419 & .159 & 3.954 \\
\hline $\begin{array}{l}\text { - Teachers' practices on sports safety in urban } \\
\text { and rural primary schools. }\end{array}$ & 137 & 135 & .874 & .384 & .0685 \\
\hline $\begin{array}{l}\text { - Teachers' practices on sports safety in urban } \\
\text { and rural secondary schools. }\end{array}$ & 131 & 129 & -1.270 & .206 & -.1182 \\
\hline $\begin{array}{l}\text { - Teachers' practices on sports safety between } \\
\text { primary and secondary schools. }\end{array}$ & 268 & 266 & 1.131 & .259 & .0619 \\
\hline
\end{tabular}

The study showed there is no difference in the quality of administrative management on sports safety in primary and secondary schools between urban and rural areas $\left(t_{57}=-.822, p>.05\right) ;\left(t_{48}\right.$ $=-.316, p>.05)$. Similarly, the study showed almost no difference in the quality of administrative management on sports safety between primary schools compared to secondary schools with Mean $=3.95\left(t_{107}=1.419, p>.05\right)$. While the comparison of teachers' practice compliance in urban and rural primary schools was also found to be insignificant ( $\left.t_{129}=-1.270, p>.05\right)$ with a mean difference of .068. For secondary schools, the average teachers' practices compliance with sports safety for urban schools was insignificant $\left(t_{129}=-1.270, p>.05\right)$ with a difference of Mean $=.1182$ compared to rural schools. The results also found that the compliance of teachers' practice with sports safety between primary and secondary schools is not significant $\left(t_{266}=1.131\right.$, p> .05; Mean Difference $=.0619$ ).

Based on the results of the study, it is illustrated that irrespective of the type, category, and location of the school, the administrators were able to manage sports safety in schools. Management in sports safety can be implemented by the administrator in accordance to the standard operating procedures based on the Safe School Policy and the Hygiene, Health, and Safety (3K) program. Similarly, the results of the study on the compliance of the teachers' practices with sports safety in primary and secondary schools in urban and rural areas were found to have no significant differences. This may due to the teachers have been exposed to safety 
Vol. 10, No. 2, 2021, E-ISSN: 2226-6348 @ 2021 HRMARS

aspects measures through the Professional Circular Letter and Handbook of Management of Physical Education and Health Education subject published by Inspectorate Board (2019).

The Relationship between the Quality of the Administrative Management and the Teachers' Practices Compliance with Sports Safety in Primary and Secondary Schools

Table 6 shows the Pearson correlation statistics data analysis on the relationship between the quality of the administrative management and the compliance of the teachers' practices with sports safety in primary and secondary schools. The results of the study showed a very strong relationship $(r=.848$, sig $=.000$ ) between the quality of the administrative management and the compliance of the teachers' practices with sports safety in primary schools. There was also a very strong relationship ( $r=.948$, sig $=.000$ ) between the quality of the administrative management and the compliance of the teachers' practices with sports safety in secondary schools.

Table 6. The relationship between the administrative management and the teaching practice with sports safety in primary and secondary schools of urban and rural areas

\begin{tabular}{|c|c|c|c|}
\hline & $n$ & $r$ & sig \\
\hline $\begin{array}{l}\text { - The relationship between administrative management and } \\
\text { teachers' practices with sports safety in primary schools }\end{array}$ & 137 & $.848^{* *}$ & .000 \\
\hline $\begin{array}{l}\text { - The relationship between administrative management and } \\
\text { teachers' practices with sports safety in secondary schools }\end{array}$ & 131 & $.948 * *$ & .000 \\
\hline $\begin{array}{l}\text { - The relationship between administrative management and } \\
\text { teachers' practices with sports safety in primary and secondary } \\
\text { schools }\end{array}$ & 268 & $.902 * *$ & .000 \\
\hline
\end{tabular}

Overall, there was a very strong relationship $(r=.902$, sig $=.000)$ between the quality of the administrative management and the compliance of the teachers' practices with sports safety in primary and secondary schools. The relationship implied that administrators and teachers have taken note and action on sports safety issues based on standard guidelines in a handbook so that students' safety is ensured in school organizations.

In the handbook contains item 1.7 on the PEHE Teaching and Learning Implementation Rules in paragraph e. (page 15) that is, the teacher who is responsible for ensuring the safety of students during the teaching and learning process of PEHE whether inside or outside the classroom, is responsible for taking out, using and storing PEHE/ sports equipment even if assisted by students, and ensuring the area used for the teaching and learning process of PEHE is in a good and manageable condition.

In item 2.14 (page 30) is related to the Sports Room and the PEHE Subject Corner, states that the subject teacher in charge must:

a. Ensure that the sports room or PEHE subject corner can function effectively.

b. Ensure the sports room is always clean, tidy, and organized.

c. Ensure that the information in the corner of PEHE subject is always updated.

d. Make full use of the facilities available in the sports room for the teaching and learning process. 
Vol. 10, No. 2, 2021, E-ISSN: 2226-6348 @ 2021 HRMARS

e. Provide guidelines and rules for the use of sports rooms, taking out and storage of sports equipment, and ensure that monitoring aspects are implemented.

f. Provide a record book of borrowing and return of equipment.

g. Record the borrowing and return of equipment in the sports room.

h. Implement equipment stock inspections at least once a year.

i. Ensure that safety aspects are given attention.

The Ministry of Education Malaysia is also very concerned about the safety of students during Physical Education and co-curricular activities by issuing several professional circulars letter since 1995, including Circular No. 1/1995: Student personal safety during the teaching of Physical Education and Health and co-curricular activities and sports inside and outside the school grounds, and Circular No. 9/2000: Student personal safety guide during Physical Education and Health Education teaching as well as co-curricular, and sports activities inside and outside the school grounds. Most recently, the MOE Circular No. 5/2016 highlights the safety guide during the teaching of Physical Education and Health as well as co-curricular activities and sports inside and outside the school grounds.

Therefore, all parties, namely administrators, teachers, and students need to play a role in addressing safety aspects, especially in Physical Education activities, co-curriculum, and sports programs. The roles that need to be given priority and attention include:

a. Carry out Physical Education activities, co-curriculum, or sports programs based on the plan that has been set according to the correct processes and procedures.

b. Identify Physical Education activities, co-curriculum, or sports programs that are appropriate and capable of the physical standard and fitness of students.

c. Inspect sports areas and equipment before and during Physical Education activities, cocurriculum or sports programs are implemented.

d. Provide understanding and awareness to students about the importance of personal safety while attending Physical Education activities, co-curriculum, or sports programs.

e. Ensure that students are fully sport-attired (according to school rules) during Physical Education activities, co-curriculum, or sports programs.

f. Inform parents or guardians about Physical Education activities, co-curriculum or sports programs that require consent letters from them.

g. Monitor and supervise the movement of students during the implementation of Physical Education activities, co-curriculum, or sports programs.

h. Ensure that students abide by the safety instructions while attending Physical Education activities, co-curriculum, or sports programs.

The current practises in Malaysia are in line with the implementation by most developed countries such as the United States, Britain, Australia, and foreign countries, policies have been set on the implementation of sports safety management in schools (U.S. Department of Health and Human Services, 2019; Education Government U. K., 2019; ACT Education Directorate, 2017). These countries also provide standard safety management guidelines or frameworks. The United States uses The Management of Safety in Physical Education and Outdoor Activities, and Risk Management Guide for Community Sports Organization (Laroche \& Corbett, 2010). Meanwhile, Britain uses Safety in Sport: Guidance for UK National Governing Bodies (Fuller, 1999). In Australia, they use Guidelines for the Safe Conduct of Sport and Physical Activity in Schools 
(Sobski, 1999). The use of these guidelines indicates that foreign organizations take serious responsibility in implementing sports programs or activities that use safety management guidelines and frameworks in sports.

\section{Conclusion}

This study concludes that the quality standard of the administrative management on sports safety in primary and secondary schools of urban and rural areas was at an excellent standard. Similarly, the compliance of the teachers' practices with sports safety in primary and secondary schools of urban and rural areas was at a very high standard. It was also found that there was no difference in the quality standard of the administrative management and the compliance of the teachers' practices with sports safety in primary and secondary schools between urban and rural areas. It is found that there was a very strong and significant relationship between the quality standard of the administrative management with the compliance of the teachers' practices with sports safety in primary and secondary schools of urban and rural areas.

Therefore, the implications of this study require administrators and teachers to pay attention to issues and action to be taken based on standard guidelines so that student safety is ensured in the school organization. The report on sports safety should be regularly submitted to the Malaysia Ministry of Education, the community, and parents so that they are confident in the safety of students in schools. The accidents in school are still the issues, while this study prevailed the implementation of sports safety is in order. Therefore, is recommended schools to conduct a safety compliance audit of sports facilities and observation on the teachers' compliance practices with the safety aspects in conducting sports activities in schools.

\section{Acknowledgement}

The authors acknowledge the financial support from the Fundamental Research Grant Scheme: Code 2019-0040-107-02 (FRGS/ 1/2018/ SSI09/ UPSI/ 01/4). The title of the research is the CAI Model Approach (Context, Audit, and Index) in Risk Management on Sports Safety in Schools. Researchers would like to thank the Research and Innovation Management Center of Sultan Idris Education University for awarding this grant.

\section{References}

ACT Education Directorate. (2017). Physical Education and Sport Policy. Retrieved on the $10^{\text {th }}$ of April 2020. www.education.act.gov.au

Harian, B. (2020). Pelajar cedera di mata tertusuk anak panah. Retrieved on 9 Februari 2020. www.bharian.com.my/berita/kes/2020/02/653657/pelajar-cedera-di-mata-tertusuk-anakpanah.

Education Government UK. (2019). School sport and activity action plan. Department for Education, Department for Digital, Culture, Media and Sport, and Department for Health and Social Care. UK: Crown Publication.

Fuller, C. W. (1999). Safety in Sport: Guidance for UK National Governing Bodies. England, United Kingdom: UK Sport. 
Inspectorate Board. (2019). Buku Panduan Pengurusan Mata Pelajaran Pendidikan Jasmani dan Pendidikan Kesihatan (PJPK), Sekolah Rendah dan Sekolah Menengah. Putrajaya: Kementerian Pendidikan Malaysia.

Laroche, D. B., \& Corbett, R. (2010). Risk Management Guide for Community Sport Organizations. Canada: Legacies Now.

Professional Circular Letter No. 1/1995: Student personal safety during the teaching of Physical Education and Health and co-curricular activities and sports inside and outside the school grounds. Kuala Lumpur: Ministry of Education Malaysia.

Professional Circular Letter No. 5/2016: The safety guide during the teaching of Physical Education and Health as well as co-curricular activities and sports inside and outside the school grounds. Kuala Lumpur: Ministry of Education Malaysia.

Professional Circular Letter No. 9/2000: Student personal safety guide during Physical Education and Health Education teaching as well as co-curricular, and sports activities inside and outside the school grounds. Kuala Lumpur: Ministry of Education Malaysia.

School Division, Ministry of Education. (2002). Konsep dan manual sekolah selamat: Panduan pelaksanaan menjadikan sekolah, komuniti dan keluarga selamat untuk kanak-kanak. Kuala Lumpur: KPM.

School Division, Ministry of Education. (2004). Program 3K: Membudayakan sekolah selamat dan sejahtera. Kuala Lumpur: KPM.

Smith, S. (2018). Determining sample size: How to ensure you get the correct sample size. Retrieved on $10^{\text {th }}$ of February 2020 https://www.qualtrics.com/blog/determinig sample size

Sobski, J. (1999). Guidelines for the safe conduct of sport and physical activity in schools. New South Wales: Department of Education and Training. 